\title{
ОСОБЛИВОСТІ ДЕТЕРМІНАЦІЇ ГОТОВНОСТІ ДО ЗМІН СЕРЕД МАЙБУТНІХ УКРАЇНСЬКИХ ПРАВООХОРОНЦІВ
}

\author{
Стояцька Ганна \\ Дніпропетровський державний університет внутрішніх справ, \\ м. Дніпро, Україна \\ e-mail: a.sagdianna@gmail.com \\ ORCID https://orcid.org/0000-0002-6501-6703
}

Мета. У статті досліджено проблему психологічних чинників сприйняття змін майбутніми українськими поліцейськими. Метою дослідження стало доведення концептуальної гіпотези про існування низки психологічних чинників, що здатні впливати на рівень готовності до змін серед курсантів, які здобувають вищу освіту i проходять підготовку до роботи в Національній поліції України.

Методи. В ході дослідження було застосовано факторний аналіз (factor analysis, component analysis) з основними методами, що були використані при побудові факторної моделі - метод головних компонент (Principal Component Analysis) та метод обертання (Varimax із нормалізацією Кайзера).

Результати. На прикладі вибірки курсантів, які навчаються в українських закладах вищої освіти із специфічними умовами навчання, проведено дослідження тих психологічних чинників, які зумовлюють сприйняття змін особистістю. В дослідженні використано 8 методик та 13 показників. Вперше для дослідження готовності до змін серед майбутніх правоохоронців застосовано визначення рівня мислення зростання та імпліцитних теорій навчання (за методиками C. Dweck). Результати дослідження стали основою для проведення факторного аналізу для зниження розмірності та виділення компонентів, що визначають структуру взаємозв'язку між досліджуваними показниками. В ході дослідження було вдосконалено уявлення про готовність до сприйняття змін майбутніми працівниками правоохоронних органів через емпіричну верифікацію таких i детермінант як професійна мотивація, відкритість новому досвіду, мотивація до успіху, соціальна адаптивність. Також було доповнено комплексне розуміння основних психологічних чинників, що впливають на формування готовності сприймати зміни молодими правоохоронцями.

Висновки. До висновків дослідження можна віднести встановлення того факту, що в структурі особистості майбутнього правоохоронця можна виділити два ортогональних фактори (компоненти), детермінованих різними наборами

ISSN 2308-3743 (Online), ISSN 2227-1376 (Print)

(C) Стояцька Г., 2021. Ця стаття відкритого доступу на умовах CC BY-NC 4.0 
змінних. Отримані компоненти було визначено як проактивну та реактивну складову особистості щодо готовності сприймати зміни та реагувати на них.

Ключові слова: зовнішня позитивна мотивація, внутрішня мотивація, толерантність до двозначності, адаптивність, факторний аналіз, правоохоронна діяльність, психологічні детермінанти

Stoyatska Ganna. Determination peculiarities of readiness for changes among future Ukrainian law enforcement officers.

Purpose. The article examines psychological factors associated with acceptance of changes by future Ukrainian police officers. The purpose of the study is to prove the conceptual hypothesis of an existence of a number of psychological factors that can affect the level of readiness for changes among cadets who pursue higher education and are trained to work in the National Police of Ukraine.

Methods. In the course of the study, factor analysis was applied along with the main methods that were used to construct the factor model - Principal Component Analysis and Rotation Method: Varimax with Kaiser Normalization.

Results. The results of the study: based on a sample of cadets studying in Ukrainian higher education institutions with specific learning conditions, there was done a research of those psychological factors that determine the acceptance of changes by personality. The study provided an essential set of 8 methods and 13 indicators. For the first time to determine the readiness for changes among future law enforcement officers the level of growth thinking and implicit theories of learning were researched (using methodology of studying by $\mathrm{C}$. Dweck). The results of the study became the basis for conducting factor analysis to reduce the dimension and highlight the components that determine the structure of the relationship between the studied indicators. This research improved the idea of readiness for acceptance of changes by future law enforcement officers. Such readiness determinants as professional motivation, openness to new experience, motivation for success, social adaptability were verified empirically. A comprehensive understanding of the main psychological factors which influence the formation of readiness to accept changes by young law enforcement officers was also supplemented.

Conclusions. The conclusions of the study include the establishment of the fact that personality structure of the future law enforcement officer can include two orthogonal factors (components), determined by different sets of variables. The components under investigation were defined as proactive and reactive components of personality in terms of readiness to accept changes and respond to them.

Keywords: external positive motivation, internal motivation, tolerance to ambiguity, adaptability, factor analysis, law enforcement, psychological determinants.

Стояцкая Анна. Особенности детерминации готовности к изменениям среди будущих украинских правоохранителей.

Цель. В статье исследуется проблема психологических факторов восприятия изменений будущими украинскими полицейскими. Целью 
исследования стало доказательство концептуальной гипотезы о существовании ряда психологических факторов, способных влиять на уровень готовности к изменениям среди курсантов, которые одновременно получают высшее образование и проходят подготовку к работе в Национальной полиции Украины.

Методы. В ходе исследования был применен факторный анализ (factor analysis, component analysis) с основными методами, которые использовались при построении факторной модели - метод главных компонент (Principal Component Analysis) и метод вращения (Varimax с нормализацией Кайзера).

Результаты исследования: на примере выборки курсантов, обучающихся в украинских учреждениях высшего образования со специфическими условиями обучения, проведено исследование тех психологических факторов, которые обусловливают восприятие изменений личностью. В исследовании использованы 8 методик и 13 показателей. Впервые для исследования готовности к изменениям среди будущих правоохранителей применено определение уровня установки на рост и имплицитных теорий обучения (по методикам C. Dweck). Результаты исследования стали основой для проведения факторного анализа для снижения размерности и выделения компонентов, определяющих структуру взаимосвязи между исследуемыми показателями. В ходе исследования было усовершенствовано представление о готовности к восприятию изменений будущими сотрудниками правоохранительных органов через эмпирическую верификацию таких ее детерминант как профессиональная мотивация, открытость новому опыту, мотивация к успеху, социальная адаптивность. Также было дополнено комплексное понимание основных психологических факторов, влияющих на формирование готовности воспринимать изменения молодыми правоохранителями.

Выводы. К выводам исследования можно отнести установление того факта, что в структуре личности будущего стража порядка можно выделить два ортогональных фактора (компоненты), детерминированных различными наборами переменных. Полученные компоненты были определены как проактивная и реактивная составляющие личности относительно готовности воспринимать изменения и реагировать на них.

Ключевые слова: внешняя положительные мотивация, внутренняя мотивация, толерантность к двусмысленности, адаптивность, факторный анализ, правоохранительная деятельность, психологические детерминанты.

Вступ. Актуальність обраної для дослідження теми зумовлена розумінням готовності до змін як процесу особистісного розвитку та підвищення адаптивних можливостей у професії, пов’язаній зі стресом, несприятливими психологічними та емоційними станами, потребою у поведінковій варіативності. Саме таким $є$ фах поліцейського. Дослідження здатності та готовності до адекватного реагування на зміни у майбутніх правоохоронців $\epsilon$ невід'ємною 
складовою загальної кадрової політики Національної поліції. Нова парадигма підготовки працівників Національної поліції, започаткована у 2015 році, вимагає нових принципів відбору професійних кадрів на службу та обгрунтування стандартів професійної діяльності з урахуванням сучасних потреб українського суспільства, орієнтованого на кращі світові стандарти правоохоронної діяльності.

Мета дослідження полягає у вивченні психологічних детермінант, які формують готовність до змін у середовищі майбутніх правоохоронців. Завдання роботи полягають у: 1) емпіричному вивченні низки психологічних чинників, які зумовлюють готовність особистості до змін та 2) проведенні факторного аналізу для виділення релевантної факторної моделі, яка б оптимально описувала готовність до змін на основі даних, отриманих під час емпіричного вивчення вибірки майбутніх поліцейських.

Методи та процедура дослідження. Основою дослідження став факторний аналіз із застосуванням методу головних компонент та методу обертання Varimax. Емпіричне дослідження проводилось із застосуванням психодіагностичних методик на визначення рівня інновативності та готовності до змін (В.Є.Клочко, О. М. Краснорядцева), адаптивності й толерантності до двозначності (Personal change readiness survey у адаптації Н. А. Бажанової i Г. Л. Бардієр), опитувальника імпліцитних інтенцій навчання i мислення зростання К. Двек (розробники Т. В. Корнілова, С. Д. Смірнов), професійної мотивації (типу мотиваційного комплексу) (К. Замфір в модифікації А. Реана), мотивації до успіху (Т. Елерса), п'ятифакторного опитувальника особистості TIPI (TIPIUKR) (українська адаптація М. Б. Кліманської, I. I. Галецької показник відкритості новому досвіду), шкали соціальної адаптивності (О. П. Саннікової, О. В. Кузнєцової), визначення рівня психологічного благополуччя (шкала К. Ріфф у версії Н. Н. Лепешинського). Математико-статистичний обрахунок масиву даних, отриманих в ході дослідження, здійснено за допомогою SPSS Ta JASP.

Для всебічного вивчення рівня готовності до сприйняття змін та психологічних чинників, які впливають на ऑї формування, було обрано цільову групу молодих правоохоронців. Вибірку дослідження 
склали курсанти українських закладів вищої освіти із специфічними умовами навчання, які здобувають освіту за освітньо-професійною програмою 262 «Правоохоронна діяльність» за принципом «2 роки курсант, 1 рік - слухач» (Джагупов, 2020), та на третьому році навчання набуватимуть практичних навичок у підрозділах Національної поліції (Наказ МВС України № 427 від 30.05.2019 року). Ця програма передбачає «здобуття освіти на денній формі протягом 1 та 2 років навчання та на заочній формі - протягом третього року навчання із направленням у розпорядження Національної поліції для подальшого проходження служби». Це принципово нова процедура підготовки поліцейських, які згодом стануть працівниками підрозділів кримінальної поліції, карного розшуку, підрозділів превентивної діяльності та поліцейськими офіцерами громади. Вибірку дослідження склали курсанти українських університетів внутрішніх справ віком від 17 до 20 років. Загалом у дослідженні взяли участь 103 курсанти, що може бути репрезентативним показником щодо генеральної сукупності. Гендерний розподіл вибірки склали 77 хлопців та 26 дівчат, що на сьогодні загалом відповідає гендерному розподілу працівників правоохоронних органів (Стояцька, 2021). А отже, цю вибірку можна назвати гетерогенною за статтю і гомогенною за віком. Одразу необхідно зазначити, що спеціального вимірювання гендерних особливостей сприйняття змін у рамках запропонованого дослідження не проводили.

Обговорення результатів. Варто зауважити, що знання рівня готовності до сприйняття змін, а також тих психологічних чинників, якими така готовність зумовлена, необхідні не лише для відбору працівників Національної поліції на службу, але й для прогнозування їхньої майбутньої професійної діяльності, для визначення майбутніх траєкторій їхнього розвитку, спеціалізації, для оптимізації їхньої психологічної підготовки, для корекції поведінки, надання психологічної допомоги у професійній діяльності, з їі особливими, часто екстремальними та стресогенними умовами праці. Тому вивчення сприйняття змін в специфічному середовищі працівників силових структур спорадично здійснюється науковцями, зацікавленими в ефективному реформуванні правоохоронних органів України. Серед найбільш вагомих вітчизняних наукових доробків можна назвати роботи В. I. Барко і В.П. Остаповича (Барко \& 
Остапович, 2019), О. А. Галустян, Л. М. Захаренко, Т. І. ЮрченкоШеховцової (Галустян, Захаренко, \& Юрченко-Шеховцова, 2017), О. В. Мітрошкіної (Мітрошкіна, 2018), С. С. Колесніченко, Я. В. Мацегори, I. І. Приходька (Колесніченко, Мацегора, Приходько, \& та ін., 2017), В. Сокуренка, Д. Швеця, В. Уварова (Сокуренко, Швець, \& Уваров, 2018) та ряду інших. Ресурсна база наукових праць вітчизняних учених, які вивчають феномен готовності особистості до змін, $\epsilon$ надзвичайно потужною та представлена авторитетними дослідженнями Л.М.Карамушки, М.В.Москальова, О.С.Толкова (Карамушка \& Москальов, 2001), (Карамушка \& Толков, 2015), А. А. Шиліної, А. О. Низовець (Шиліна \& Низовець, 2016), Н. С. Муромець, О. А. Мельниченко. (Муромець \& Мельниченко, 2016), О.В.Диси (Диса, 2020), І.В.Бринзи, М. Ф. Будіянського (Бринза \& Будіянський, 2016), іншими працями, які стосуються вивчення реакцій на зміни та інновації працівників різних сфер та організацій.

3 найбільш потужних закордонних досліджень варто зазначити доробки I. Адзізеса (Адзізес, 2018), К. Двек, Д. Ягера (Dweck, 2016), (Yeager \& Dweck, 2020), С. Рольніка, Н. Хереза, Р. Голда, В. Халла (Rollnick, Heather, Gold, \& Hall, 1992). Одна з найбільш оригінальних інтерпретацій поняття «готовність до змін» грунтується на концепції Growth mindset (мислення зростання), розробленій та обгрунтованій американською професоркою психології Carol S. Dweck, що тривалі роки вивчала феномен сили людських установок і переконань та їхнього впливу на життя особистості, кар'єрне зростання, самооцінку особистістю власних сил, можливостей та вмінь. Розроблені нею методики, що спрямовані на визначення рівня самооцінки інтелекту, імпліцитних інтенцій навчання та, власне, мислення зростання (Growth mindset) є інструментами, завдяки яким відбувається виявлення здібностей до наполегливого розвивання власної продуктивності, успішності, стійкості до криз, інтелектуальної зрілості, готовності до змін та невдач. Об'єднана адаптована методика імпліцитних інтенцій навчання, в основу якої покладено вивчення готовності до змін, використана в нашому дослідженні. Для вивчення майбутніх українських правоохоронців цю методику застосовано вперше.

Для проведення математико-статистичних обробок даних всі отримані в ході дослідження показники було перевірено на 
нормальність розподілу даних за критерієм Шапіро-Уілка. Показники по всіх шкалах мали нормальний розподіл $(\mathrm{p}<0,05)$. Для аналізу кореляційних зв'язків між змінними використано коефіцієнт кореляції Пірсона.

Встановлено, що за отриманими у нашій вибірці даними показник готовності до змін демонструє високу пряму кореляцію (вище 0,6) з показниками загального мотиваційного комплексу $(0.623 * * * ; \quad * * *-p<0,001)$, внутрішньої мотивації $(0.593 * * *$; ***_ $\mathrm{p}<0,001)$, зовнішньої негативної мотивації $(0.665 * * * ; * * *-p<0,001)$, відкритості новому досвіду $(0.735 * * * ; * * *-p<0,001)$, мотивації до успіху $(0.768 * * * ; * * *$-р $<0,001)$. Середні показники кореляції (від 0,4, до 0,6) $з$ показниками мислення зростання (Growth mindset) та імпліцитних інтенцій навчання $(0.574 * * * ; * * *-p<0,001)$, зовнішньої позитивної мотивації $(0.541 * * * ; \quad * * *$-p<0,001), соціальної адаптивності $(0.604 * * *$; ***-p $<0,001)$. Низьку або відсутню кореляцію 3 показниками рівня психологічного благополуччя $(0.243 *$; $*$-р $<0,05)$, адаптивності (0.078; *-p<0,05), толерантності до двозначності (-0.05; *-p<0,05). Варто зазначити, що достатньо високі показники кореляції між змінними пов'язані, вочевидь, зі специфікою вибірки курсантів, які проходять психологічний відбір на навчання та на службу. Адже зазвичай дослідження демонструють, що серед курсантської аудиторії домінує гіпертимний тип 3 достатньо високим рівнем мотивації до обраного фаху.

Після отримання даних кореляційного аналізу стало очевидним, що подальше дослідження вимагає здійснити факторний аналіз масиву даних, оскільки саме він призначений для виділення чинників, які впливають на ту чи ту психологічну особливість або якість. Оскільки факторний аналіз як метод виник саме 3 психології і він дозволяє класифікувати ознаки, то побудова факторної моделі в нашому випадку є цілком виправданою.

По-перше, факторний аналіз можна використати як метод стиснення даних. Тобто у нас $є 13$ ознак (предикторів), які відображають певні особливості готовності особистості до сприйняття змін. I ми б хотіли на їх основі побудувати модель на підставі таких ознак, функціональність яких дозволила б нам зберегти суттєву інформацію і залишити 3 першопочаткового набору ті, які необхідним і достатнім чином відображають особливості нашої вибірки. 
Інший спосіб використання факторного аналізу - це ідентифікація ознак, і цей метод використання найцікавіший, принаймні в нашому випадку дослідження готовності до змін. Адже ми досліджуємо схильност,і коли у нас $є$ широкий діапазон вияву готовності до змін і ми намагаємося шляхом математикостатистичної обробки даних дослідити, які саме психологічні чинники іï викликають, якими $є$ внутрішні механізми, що структурують кількість характеристик даної змінної. Через наявність в нашому масиві даних мультиколінеарних ознак, ми не можемо повністю покладатись на альтернативні методи дослідження, оскільки наявність мультиколінеарності може знижувати точність отриманих коефіцієнтів. В рамках факторного аналізу простір ознак, які певним чином пояснюють готовність особистості до змін, буде перенесено в нову факторну модель 3 певною сумарною проясненою дисперсією.

Факторний аналіз - метод творчий i розвідувальний, коли алгоритм обирає певну спільність, а ми шляхом інтерпретації результатів спробуємо продемонструвати, що ж стоїть за цим групуванням і наскільки вибірка адекватна поставленим завданням. У факторну модель у нас входять загалом 13 змінних (показників). Факторний аналіз, фактично, означає зниження розмірності. Для результатів факторного аналізу найкращими показниками $\epsilon$ відбирання алгоритмом найменшої кількості факторів.

Методом витягу було обрано метод головних компонент як статистично обгрунтований. Обов'язковою умовою побудови факторної моделі є врахування таких статистичних характеристик: КМО (міра адекватності вибірки Кайзера-Мейера-Олкіна) та критерію сферичності Бартлета (значимість >0,05 засвідчуватиме, що проведення факторного аналізу $є$ прийнятним). Саме вони дозволяють оцінити якість моделі, побудованої методом головних компонент. Для алгоритму екстракції даних було залишено грунтування на власному значенні (за умови цього власного значення більше, ніж одна пояснена дисперсія). Також для моделі було задано обертання Varimax як такий, що дозволяє підвищити контрастність даних. Серед параметрів також було задано виключення низьких коефіцієнтів із граничним значенням 0,3.

За результатами першої побудованої факторної моделі було отримано такі міри якості: КМО - 0,796 (пороговий КМО більший 
ніж 0,5); значимість критерію Бартлета <0,001 - фактично нульовий рівень значимості означає, що ми приймаємо альтернативну гіпотезу про те, що існують взаємозв'язки між змінними, а отже, побудова факторної моделі має сенс. За результатами, всі ознаки увійшли в модель 3 вихідною одиничною дисперсією, і велика кількість цієї дисперсії в підсумку визначила іiі результати: готовність до змін 0,667 , загальна інновативність - 0,754, адаптивність - 0,864, толерантність до двозначності - 0,858, рівень психологічного благополуччя - 0,798, мислення зростання та імпліцитні інтенції 0,783, мотиваційний комплекс - 0,876, внутрішня мотивація $-0,632$, зовнішня негативна мотивація - 0,743 , зовнішня позитивна мотивація - 0,803, відкритість новому досвіду - 0,706, мотивація до успіху 0,794, соціальна адаптивність - 0,646. Загальна пояснена дисперсія цієї моделі склала 76,35 \%, а 313 ознак було виділено 3 фактори.

Основні дані за групуванням факторів першої факторної моделі (під час здійснення факторного аналізу застосовано метод Varimax): Перший виділений фактор виявився навантажений десятьма змінними: мотиваційний комплекс 0,926, зовнішня позитивна мотивація 0,854 , зовнішня негативна мотивація 0,848 , мотивація до успіху 0,822, готовність до змін 0,812, відкритість новому досвіду 0,805 , загальна інновативність 0,803 , мислення зростання та імпліцитні інтенції навчання 0,800, соціальна адаптивність 0,800, внутрішня мотивація 0,758. Другий фактор отриманої моделі - двома змінними: толерантність до двозначності 0,923, адаптивність 0,921. Третій фактор - чотирма змінними, серед яких три - 3 досить низьким рівнем значущості: мотивація до успіху 0,319, готовність до змін, загальна інновативність 0,319, мислення зростання та імпліцитні інтенції навчання 0,377, рівень психологічного благополуччя 0,891 .

Результати наочно показують, що така змінна як рівень психологічного благополуччя фактично стоїть осторонь від сукупності інших змінних, які увійшли як чинники в модель i, по суті, одна визначає третій фактор. Враховуючи, що найбільш оптимальною факторною моделлю $є$ та, в межах якої виділяється найменша кількість факторів, виникає доцільність переглянути перебування цієї змінної у моделі факторного аналізу. Тому ми виключили цей показник 3 наших даних і перезапустили модель вже на 12 факторах. 
Після перебудови факторної моделі було отримано попередні перевірочні результати: КМО моделі більше ніж 0,822 (пороговий КМО, більший ніж 0,5) та нульова значимість критерію Бартлета (рівень значимості означає, що ми, як i раніше, приймаємо альтернативну гіпотезу).

Табличя 1

Таблиця відсотків виділеної дисперсії досліджуваних показників

\begin{tabular}{|l|r|r|}
\hline & Вхідний рівень & Виділений рівень \\
\hline Готовність до змін & 1,000 & 0,639 \\
\hline Загальна інновативність & 1,000 & 0,697 \\
\hline Адаптивність & 1,000 & 0,857 \\
\hline Толерантність до двозначності & 1,000 & 0,848 \\
\hline $\begin{array}{l}\text { Мислення зростання та імпліцитні } \\
\text { інтенції навчання }\end{array}$ & 1,000 & 0,699 \\
\hline Внутрішня мотивація & 1,000 & 0,619 \\
\hline Зовнішня негативна мотивація & 1,000 & 0,721 \\
\hline Зовнішня позитивна мотивація & 1,000 & 0,672 \\
\hline Відкритість новому досвіду & 1,000 & 0,691 \\
\hline Мотивація до успіху & 1,000 & 0,737 \\
\hline Соціальна адаптивність & 1,000 & 0,622 \\
\hline Мотиваційний комплекс & 1,000 & 0,830 \\
\hline
\end{tabular}

Метод екстракції: Метод головний компонент.

Таблиця 1 представляє міру дисперсії, 3 якою кожна змінна вийшла з нашої моделі (що кожна ознака знову при вході у модель принесла одиничну дисперсію), і всі ознаки зберегли іiі істотну частину.

Загальний сумарний відсоток дисперсії нашої вибірки, прояснений другою факторною моделлю, склав 71,94 \%. Але тепер в нашій моделі виділилось вже лише два фактори.

Нижче нами представлено графік кам'янистого осипу другої факторної моделі (scree plot) (рис. 1).

Графік кам'янистого осипу (рис. 1) та обернена матриця сумарних значень виділених компонентів (табл. 2) дозволяють проінтерпретувати результати проведеного аналізу. Вони містять, власне, виділені фактори, тобто ті спільності, які утворились завдяки досліджуваним нами змінним i на підставі чого ми можемо інтерпретувати побудовану модель. 


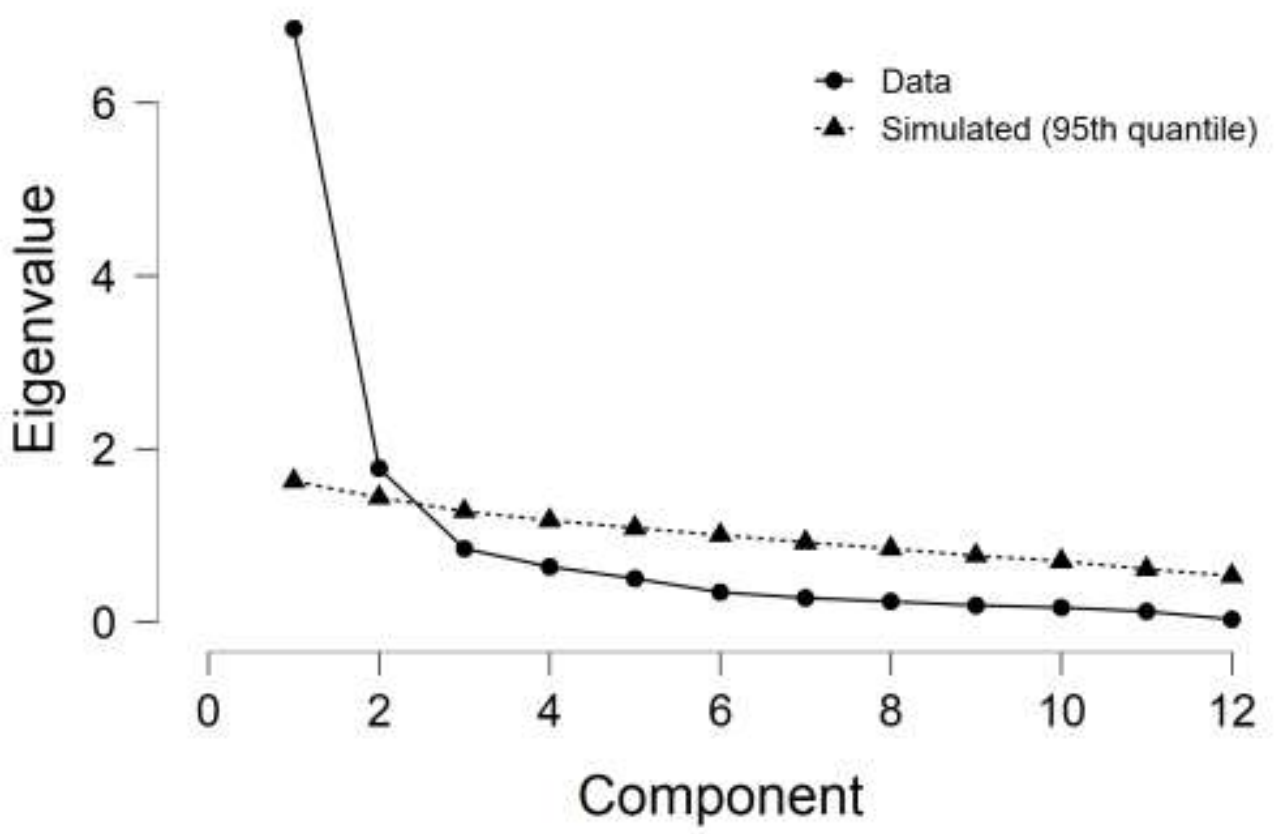

Рис. 1. Графік кам’янистого осипу другої факторної моделі

Таблиия 2

\section{Таблиця компонентів другої факторної моделі (обертання Varimax)}

\begin{tabular}{|l|c|c|}
\hline \multicolumn{2}{|c|}{ Ротована матриця компонентів } \\
\hline & 1 & \multicolumn{2}{|c|}{ Фактори } \\
\hline & 0,908 & \\
\hline Мотиваційний комплекс & 0,851 & \\
\hline Мотивація до успіху & 0,843 & \\
\hline Зовнішня позитивна мотивація & 0,835 & \\
\hline Мислення зростання & 0,832 & \\
\hline Загальна інновативність & 0,822 & \\
\hline Відкритість новому досвіду & 0,814 & \\
\hline Зовнішня негативна мотивація & 0,799 & 0,926 \\
\hline Готовність до змін & 0,788 & 0,920 \\
\hline Соціальна адаптивність & 0,773 & \\
\hline Внутрішня мотивація & & \\
\hline Адаптивність & & \\
\hline Толерантність до двозначності & \\
\hline
\end{tabular}

Метод екстракції: Метод головних компонент.

Метод обертання: Varimax із нормалізацією Кайзера. ${ }^{a}$

а. Обертання сходилось за 3 ітерації. 
Враховуючи, що завдання факторного аналізу - це отримання по можливості найменшої кількості факторів, зазначимо, що саме ця модель залишається для інтерпретації.

По-перше, ми отримали самі фактори, виділені за допомогою методу головних компонент. По-друге, ми отримали розуміння структури зв'язку між цими компонентами у нашому масиві даних. Крім цього, ми отримали кількісні показники латентних факторів, які впливають певним чином на видимі прояви широкого спектра (адже ми пам'ятаємо, що майже 28 \% нашої дисперсії факторна модель не пояснює i нам в подальшому знадобиться знаходити якісь інші чинники, які впливають на сприйняття змін в структурі особистості майбутнього правоохоронця). У програмі JASP ми побудували діаграму траєкторій (Path Diagram) обумовленості факторів змінними (рис. 2).

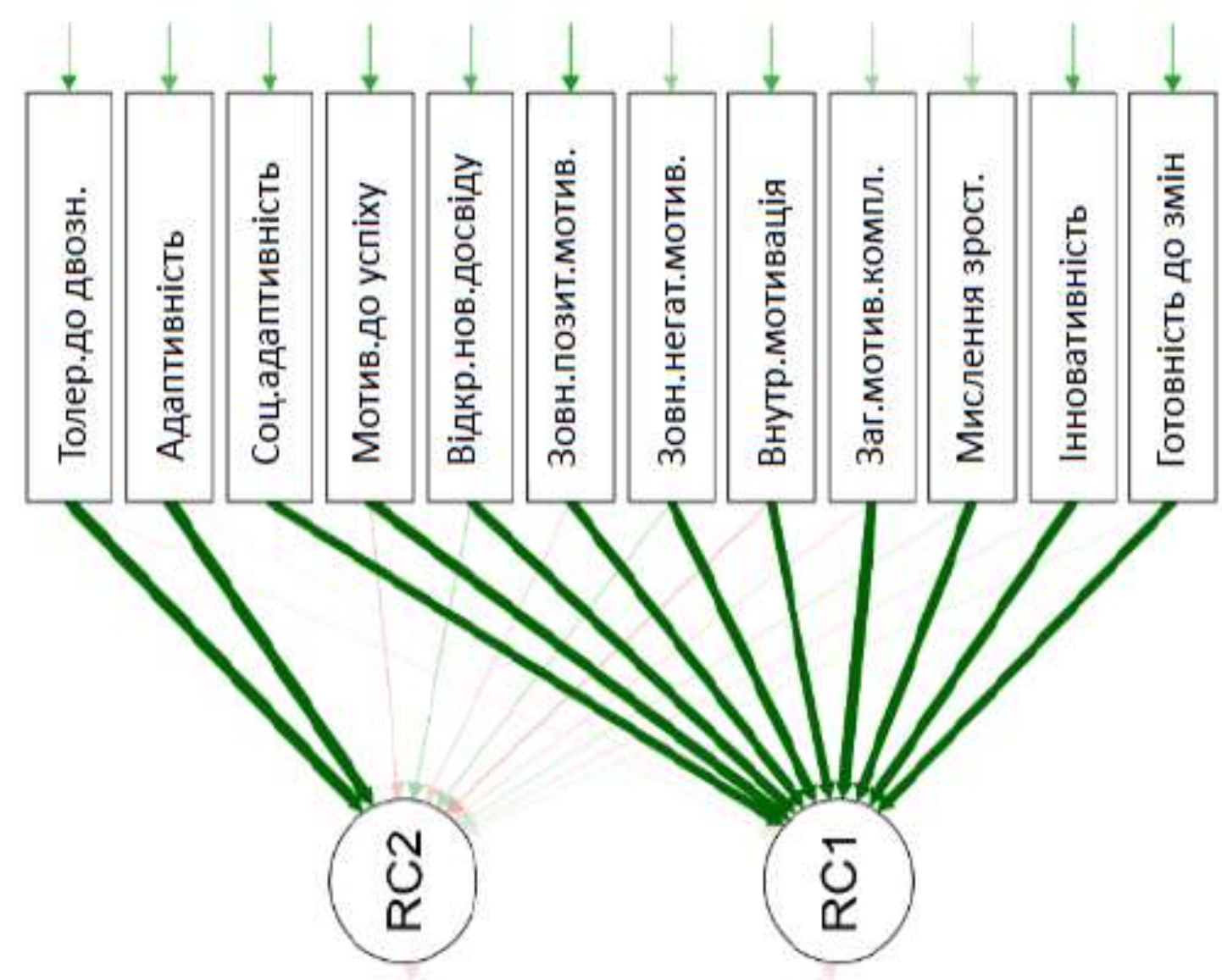

Рис. 2. Діаграма траєкторій навантаженості факторів змінними

Зокрема, перший фактор, цілком побудований на 10 змінних, які, як вважається, характеризуються високим рівнем впливу об'єктивних 
обставин. Другий фактор, навантажений двома змінними, - це фактор, який чітко демонструє домінування суто суб'єктивних ознак. Ми пам'ятаємо, що змінні, якими навантажений перший фактор, розкривають мотиваційні особливості особистості, іiі інновативність, мислення зростання та соціальну адаптивність. Тобто це якості, які показують нам потреби особистості у змінюванні соціального простору навколо себе для досягнення певної мети. Другий фактор у нас визначається двома особливостями особистості - пї толерантністю до двозначності та особистісною адаптивністю. Тобто це інтенційні психічні якості, імпліцитно притаманні особистості. Зазвичай вони $є$ більш ригідними, такими, що мало залежать від процесів самовиховання або самовдосконалення. Адже неодноразові тестування курсантів закладів системи МВС навіть на початку їхнього навчання, ще під час табірних зборів та викладання спецкурсів із толерантності, свідчать про те, що ці якості, як правило, не $є$ набутими. Вони більш притаманні людині імпліцитно. Часто вони стійко сформовані установками того соціального оточення, в якому людина зростала, соціальним кліматом, який іiі супроводжував у період становлення особистості. Ці властивості важко піддаються корегуванню, оскільки належать до глибинної сфери переконань. Отже, з'ясувавши суть того, що лежить в основі виділених факторів, ми можемо привласнити їм назви.

Ці виділені в процесі аналізу два фактори ми можемо назвати:

- мотивація особистості (проактивний фактор)

- та імпліцитна спрямованість особистості (реактивний фактор).

Висновки i перспективи. Підсумовуючи проведене дослідження, можемо констатувати, що така психологічна риса особистості як готовність до змін, на прикладі вибірки майбутніх правоохоронців, сформована двома поляризованими тенденціями. Одна 3 цих тенденцій (перший фактор) демонструє усвідомлені установки особистості на успіх, зростання, відкритість новому, здатність змінюватись не лише під тиском зовнішніх обставин, але й 3 урахуванням власних прагнень їх ініціювати. Інша тенденція, яка впливає на готовність до змін (другий фактор) - це імпліцитні усталені установки особистості, які визначають піi ставлення до двозначності та здатність до особистісної адаптивності.

Готовність до сприйняття змін є психічною якістю, яка на нашій вибірці продемонструвала цілісний комплекс чинників, які і1і 
обумовлюють. Було підтверджено наше уявлення про те, що вона пов'язана причинно-наслідковим зв'язком із різними видами мотивації та готовністю до інновацій, соціальною адаптивністю, відкритістю новому досвіду, мисленням зростання. Тому психологічну готовність до сприйняття змін можна внести до списку професійно важливих якостей для визначення їх під час проведення професійного психологічного відбору у кандидатів на посади правоохоронців.

Для перспективи подальших досліджень у цій царині, для більш ретельного вивчення особливостей готовності до сприйняття змін можна модифікувати або варіювати психодіагностичний комплекс методик, що зазвичай застосовується при відборі кандидатів на навчання та на службу, включити до переліку незалежних змінних показники на визначення типу особистості, схильності до психічних розладів, стресостійкості тощо. Такі варіативні підходи дозволять отримати більш об'єктивну картину особистості молодого правоохоронця та розвивати таку важливу рису як готовність до змін.

\section{Лiтература}

1. Carol Dweck: A summary of the two mindsets. (2021, February 05). Retrieved May 16, 2021, from https://fs.blog/2015/03/carol-dweck-mindset/

2. Chen, P., Powers, J. T., Katragadda, K. R., Cohen, G. L., \& Dweck, C. S. (2020). A strategic mindset: An orientation toward strategic behavior during goal pursuit. Proceedings of the National Academy of Sciences, 117(25), 14066-14072. DOI:10.1073/pnas.2002529117

3. Dweck, C. S. (2016). Mindset the new psychology of success. New York: Ballantine Books.

4. Dweck, C. S. (2019). The Choice to Make a Difference. Perspectives on Psychological Science, 14(1), 21-25.

5. Dweck, C. S., \& Yeager, D S. (2019). Mindsets: A view from two eras. Perspectives on Psychological Science, 14(3), 481-496. DOI:10.1177/ 1745691618804166

6. Li, Y., \& Bates, T. C. (2020). Testing the association of growth mindset and grades across a challenging transition: Is growth mindset associated with grades? Intelligence, 81, 101471. DOI: 10.1016/j.intell.2020.101471

7. Rollnick, S., Heather, N., Gold, R., \& Hall, W. (1992). Development of a short 'readiness to change' questionnaire for use in brief, opportunistic interventions among excessive drinkers. Addiction, 87(5), 743-754. DOI:10.1111/j.13600443.1992.tb02720.x

8. Yeager, D., \& Dweck, C. (2020). What Can Be Learned From Growth Mindset Controversies? American Psychologist, 75(9), 1269-1284. 
9. Yeager, D., Hanselman, P., Walton, G., Murray, ., \& Others. (2019). A national experiment reveals where a growth mindset improves achievement. Nature, 573(7774), 364.

10. Адзізес, I. К. (2018). Управління змінами. Київ: Book Chef.

11. Барко, В. І., \& Остапович, В. П. (2019). Українськомовна адаптація опитувальника Баднера для використання в Національній поліції. Психологічний часопис, 5(8), 249-263.

12. Бринза, I. В., \& Будіянський, М. Ф. (2016). Готовність до змін як ресурс подолання психологічної кризи. Наука і освіта, 11, 43-48. DOI:https://doi.org/ 10.24195/2414-4665-2016-11-9

13. Воробйова, I. В., Приходько, I. І., \& Полторак, С. Т. Автоматизований психодіагностичний комплекс визначення професійної придатності кандидатів на військову службу у внутрішні війська МВС України і навчання у вищих військових навчальних закладах МВС України. Монографія (I. I. Приходько, Ed.). Харків: НА НГУ.

14. Галустян, О. А., Захаренко, Л. М., \& Юрченко-Шеховцова, Т. І. (2017). Значення саморегуляції в професійній мотивації поліцейських. Збірник наукових праць Національної академії Державної прикордонної служби України. Серія : Психологічні науки, 2, 30-43. DOI:http://nbuv.gov.ua/UJRN/znpnapv_pn_2017_2_5

15. Галустян, О. А., Захаренко, Л. М., \& Юрченко-Шеховцова, Т І. (2017). Особливості внутрішньої та зовнішньої мотивації поліцейських до професійної діяльності: результати пілотажного дослідження. Актуальні проблеми психологіï, $\quad 46(1), \quad 3-10 . \quad$ Retrieved http://appsychology.org.ua/data/jrn/v1/i46/3.pdf

16. Галустян, О. А., Захаренко, Л. М., \& Юрченко-Шеховцова, Т. І. (2017). Особливості мотивації професійної діяльності поліцейських 3 різними мотиваційними комплексами. Вісник Національної академії Державної прикордонної служби Украӥни, 4. Retrieved from http://nbuv.gov.ua/UJRN/ Vnadpn_2017_4_6.

17. Диса, О. В. (2020). Психологічні чинники сприймання інновацій працівниками організацій. Психологія: реальність та перспективи. Збірник наукових праць РДГУ, 15, 50-58.

18. Захаренко, Л. М., Малоголова, О. О., \& Юрченко-Шеховцова, Т. І. (2018). Дослідження особливостей навчальної мотивації курсантів випускного курсу. Право і безпека - Право и безопасность - Law and Safety, 2(69), 36-42.

19. Карамушка, Л. М., \& Москальов, М В. (2001). Психологічні умови підготовки майбутніх менеджерів до управління змінами в організації: Монографія. Київ: Просвіта.

20. Карамушка, Л. М., \& Толков, О. С. (2015). Психологічні особливості опору змінам персоналом вищої школи. Організаційна психологія. Економічна психологія, 2, 35-42. 
21. Кліманська, Г. Б., \& Галецька, I. I. (2019). Українська адаптація короткого п'ятифакторного опитувальника особистості tipi (TIPI-UKR). Психологічний часопис, 5(9), 57-74.

22. Колесніченко, С. С., Мацегора, Я. В., Приходько, І. І., \& та ін. (2017). Психологічна готовність до ризику військовослужбовців Національної гвардії України: монографія. Харків: Національна академія НГУ.

23. Мітрошкіна, О. В. (2018). Специфіка психологічної готовності до змін та особистісної зрілості у працівників кримінально-виконавчої служби. Право $i$ безпека - Право и безопасность - Law and Safety, 70(3), 64-70. DOI:doi.org/ 10.32631/pb.2018.3.09

24. Назаренко, Н. А. (2020). Особистісна готовність до змін студентів як потенціал для вибору власної життєвої позиції. Науковий вісник Херсонського державного університету. Серія «Психологічні науки», 4, 63-70.

25. Наказ МВС України «Про вдосконалення підготовки курсантів у закладах вищої освіти із специфічними умовами навчання, які здійснюють підготовку поліцейських за спеціальністю «Правоохоронна діяльність» № 427 від 30.05.2019 р.

26. Сокуренко, В., Швець, Д., $\quad$ \& Уваров, В. (2018). Прогностична компетентність правоохоронців у контексті їхньої готовності до інноваційної діяльності. Science and Education, (3), 85-91.

27. Стояцька, Г. М. (2021). Гендерні аспекти готовності до сприйняття змін серед майбутніх правоохоронців. Розуміння маскулінності та тендерної рівності в секторі безпеки України та представлення результатів дослідження: матеріали Міжнар. наук.-практ. конф. (Київ, 25 берез. 2021 р.), $170-174$.

28. Технологія психологічної підготовки персоналу організацій до роботи в умовах соціально-економічних змін (на матеріалі освітніх організацій) (2008). (Л. М. Карамушка, Ed.). Київ: Науковий світ.

29. Шиліна, А. А., \& Низовець, А. О. (2016). Готовність до змін як чинник інноваційності студентів-психологів. Право і безпека, 4, 173-177.

\section{Referenses}

1. Carol Dweck: A summary of the two mindsets. (2021, February 05). Retrieved May 16, 2021, from https://fs.blog/2015/03/carol-dweck-mindset/

2. Chen, P., Powers, J. T., Katragadda, K. R., Cohen, G. L., \& Dweck, C. S. (2020). A strategic mindset: An orientation toward strategic behavior during goal pursuit. Proceedings of the National Academy of Sciences, 117(25), 14066-14072. DOI:10.1073/pnas.2002529117

3. Dweck, C. S. (2016). Mindset the new psychology of success. New York: Ballantine Books.

4. Dweck, C. S. (2019). The Choice to Make a Difference. Perspectives on Psychological Science, 14(1), 21-25. 
5. Dweck, C. S., \& Yeager, D. S. (2019). Mindsets: A view from two eras. Perspectives on Psychological Science, 14(3), 481-496. DOI:10.1177/ 1745691618804166

6. Li, Y., \& Bates, T. C. (2020). Testing the association of growth mindset and grades across a challenging transition: Is growth mindset associated with grades? Intelligence, 81, 101471. DOI:10.1016/j.intell.2020.101471

7. Rollnick, S., Heather, N., Gold, R., \& Hall, W. (1992). Development of a short 'readiness to change' questionnaire for use in brief, opportunistic interventions among excessive drinkers. Addiction, 87(5), 743-754. DOI:10.1111/j.13600443.1992.tb02720.x

8. Yeager, D., \& Dweck, C. (2020). What Can Be Learned From Growth Mindset Controversies? American Psychologist, 75(9), 1269-1284.

9. Yeager, D., Hanselman, P., Walton, G., Murray, J., \& Others. (2019). A national experiment reveals where a growth mindset improves achievement. Nature, 573(7774), 364.

10. Adzizes, I. K. (2018). Upravlinnia zminamy [Mastering Change]. Kyiv: Book Chef [in Ukrainian].

11. Barko, V. I., \& Ostapovych, V. P. (2019). Ukrainskomovna adaptatsiia opytuvalnyka Badnera dlia vykorystannia v Natsionalnii politsii [Ukrainian Language adaptation of Budner's questionnaire for use in the National Police]. Psychological Journal, 5(8), 249-263 [in Ukrainian].

12. Brynza, I. V., \& Budiianskyi, M. F. (2016). Hotovnist do zmin yak resurs podolannia psykholohichnoi kryzy [Readiness for changes as resource for overcoming psychological crisis]. Science and education, 11, 43-48. DOI:https://doi.org/10.24195/ 2414-4665-2016-11-9 [in Ukrainian].

13. Vorobiova, I. V., Prykhodko, I. I., \& Poltorak, S. T. (2016). Avtomatyzovanyi psykhodiahnostychnyi kompleks vyznachennia profesiinoi prydatnosti kandydativ na viiskovu sluzhbu u vnutrishni viiska MVS Ukrainy i navchannia u vyshchykh viiskovykh navchalnykh zakladakh MVS Ukrainy. Monohrafiia [Automated psychodiagnostic complex for determining the professional suitability of candidates for military service in the internal troops of the Ministry of Internal Affairs of Ukraine and training in higher military educational institutions of the Ministry of Internal Affairs of Ukraine. Monograph] (I. I. Prykhodko, Ed.). Kharkiv: NA NHU [in Ukrainian].

14. Halustian, O. A., Zakharenko, L. M., \& Yurchenko-Shekhovtsova, T. I. (2017). Znachennia samorehuliatsii $\mathrm{v}$ profesiinii motyvatsii politseiskykh [Importance of Self regulation in Professional Motivation of Police Force]. Zbirnyk naukovykh prats Natsionalnoi akademii Derzhavnoi prykordonnoi sluzhby Ukrainy. Seriia : Psykholohichni nauky [Collection of scientific works of the National Academy of the State Border Guard Service of Ukraine. Series: psychological sciences], 2, 30-43. doi:http://nbuv.gov.ua/UJRN/znpnapv_pn_2017_2_5 [in Ukrainian]

15. Halustian, O. A., Zakharenko, L. M., \& Yurchenko-Shekhovtsova, T. I. (2017). Osoblyvosti vnutrishnoi ta zovnishnoi motyvatsii politseiskykh do profesiinoi 
diialnosti: rezultaty pilotazhnoho doslidzhennia [Police officers' internal and external motivation for the profession: a pilot study results]. Aktualni problemy psykholohii [Actual Problems of Psychology], 46(1), 3-10. Retrieved from http://appsychology. org.ua/data/jrn/v1/i46/3.pdf [in Ukrainian]

16. Halustian, O. A., Zakharenko, L. M., \& Yurchenko-Shekhovtsova, T. I. (2017). Osoblyvosti motyvatsii profesiinoi diialnosti politseiskykh z riznymy motyvatsiinymy kompleksamy [Professional Activity Motivation Features of Policemen with Different Motivation complexes]. Visnyk Natsionalnoi akademii Derzhavnoi prykordonnoi sluzhby Ukrainy [Bulletin of the National Academy of the State Border Guard Service of Ukraine], 4. Retrieved from http://nbuv.gov.ua/UJRN/ Vnadpn_2017_4_6 [in Ukrainian].

17. Dysa, O. V. (2020). Psykholohichni chynnyky spryimannia innovatsii pratsivnykamy orhanizatsii [Psychological factors of perception of innovation by employees in organizations]. Psykholohiia: realnist ta perspektyvy. [Psychology: Realty \& Prospects], 15, 50-58 [in Ukrainian].

18. Zakharenko, L. M., Maloholova, O. O., \& Yurchenko-Shekhovtsova, T. I. (2018). Doslidzhennia osoblyvostei navchalnoi motyvatsii kursantiv vypusknoho kursu [Research of the peculiarities of academic motivation of final-year cadets]. Pravo i bezpeka - Pravo i bezopasnost - Law and Safety, 2(69), 36-42 [in Ukrainian].

19. Karamushka, L. M., \& Moskalov, M. V. (2001). Psykholohichni umovy pidhotovky maibutnikh menedzheriv do upravlinnia zminamy $v$ orhanizatsii: Monohrafiia [Psychological conditions of preparation of future managers for change management in the organization: Monograph]. Kyiv: Prosvita [in Ukrainian].

20. Karamushka, L. M., \& Tolkov, O. S. (2015). Psykholohichni osoblyvosti oporu zminam personalom vyshchoi shkoly [Psychological features of resistance to change by staff of institutions of higher education]. Orhanizatsiina psykholohiia. Ekonomichna psykholohiia [Organizational Psychology. Economic Psychology], 2, 35-42 [in Ukrainian].

21. Klimanska, H. B., \& Haletska, I. I. (2019). Ukrainska adaptatsiia korotkoho piatyfaktornoho opytuvalnyka osobystosti TIPI (TIPI-UKR) [Ukrainain adaptation of the short five factor personality questionnaire TIPI (TIPI-UKR)]. Psychological Journal, 5(9), 57-74 [in Ukrainian].

22. Kolesnichenko, S. S., Matsehora, Ya. V., Prykhodko, I. I., \& ta in. (2017). Psykholohichna hotovnist do ryzyku viiskovosluzhbovtsiv Natsionalnoi hvardii Ukrainy: monohrafiia [Psychological readiness for risk of servicemen of the National Guard of Ukraine: Monograph.]. Kharkiv: Natsionalna akademiia NHU [in Ukrainian].

23. Mitroshkina, O. V. (2018). Spetsyfika psykholohichnoi hotovnosti do zmin ta osobystisnoi zrilosti u pratsivnykiv kryminalno-vykonavchoi sluzhby [Specificity of psychological readiness for changes and personality's maturity of the employees of the state criminal and executive service]. Pravo i bezpeka - Pravo i bezopasnost Law and Safety, 70(3), 64-70. DOI:doi.org/10.32631/pb.2018.3.09 [in Ukrainian]. 
24. Nazarenko, N. A. (2020). Osobystisna hotovnist do zmin studentiv yak potentsial dlia vyboru vlasnoi zhyttievoi pozytsii [Personality readiness for changes of students as a potential for choosing their own life position]. Naukovyi visnyk Khersonskoho derzhavnoho universytetu. Seriia «Psykholohichni nauky» [Scientific Bulletin of Kherson State University. Series «Psychological Sciences»], 4, 63-70 [in Ukrainian].

25. Nakaz MVS Ukrainy «Pro vdoskonalennia pidhotovky kursantiv u zakladakh vyshchoi osvity iz spetsyfichnymy umovamy navchannia, yaki zdiisniuiut pidhotovku politseiskykh za spetsialnistiu «Pravookhoronna diialnist» [Order of the Ministry of Internal Affairs of Ukraine "On improving the training of cadets in higher education institutions with specific training conditions, which train police officers in the specialty" Law Enforcement "] № 427 vid 30.05.2019 r. [in Ukrainian].

26. Sokurenko, V., Shvets, D., \& Uvarov, V. (2018). Prohnostychna kompetentnist pravookhorontsiv u konteksti yikhnoi hotovnosti do innovatsiinoi diialnosti [Predictive competence of police officers in Terms of their readiness for innovation activity]. Science and Education, (3), 85-91 [in Ukrainian].

27. Stoyatska, G. M. (2021). Henderni aspekty hotovnosti do spryiniattia zmin sered maibutnikh pravookhorontsiv [Gender aspects of readiness to accept changes among future law enforcement officers.]. Rozuminnia maskulinnosti ta gendernoi rivnosti $v$ sektori bezpeky Ukrainy ta predstavlennia rezultativ doslidzhennia: materialy Mizhnar. nauk.-prakt. konf. (Kyiv, 25 berez. 2021 r.) [Understanding masculinity and gender equality in the security sector of Ukraine and presenting the results of the study: materials International. scientific-practical conf. (Kyiv, March 25, 2021)], 170-174 [in Ukrainian].

28. Tekhnolohiia psykholohichnoi pidhotovky personalu orhanizatsii do roboty $\mathrm{v}$ umovakh sotsialno-ekonomichnykh zmin (na materiali osvitnikh orhanizatsii) [Technology of psychological preparation of the personnel of the organizations for work in the conditions of social and economic changes (on a material of the educational organizations)] (2008). (L. M. Karamushka, Ed.). Kyiv: Naukovyi svit. [in Ukrainian]

29. Shylina, A. A., \& Nyzovets, A. O. (2016). Hotovnist do zmin yak chynnyk innovatsiinosti studentiv-psykholohiv [Gender features of status and role, Behavioral victimization of minors]. Law and Safety, 4, 173-177 [in Ukrainian].

Received: 29.04.2021

Accepted: 16.05.2021 